JeRZY TUTAJ

Politechnika Wrocławska, Polska - Wrocław University of Science and Technology, Poland

\title{
Innowacje w przedsiębiorstwie uzdrowiskowym
}

\section{Innovations in Spa Enterprises}

Streszczenie: W artykule przedstawiono potencjał i kierunki funkcjonowania przedsiębiorstw uzdrowiskowych. Przeprowadzono przegląd dotychczasowej literatury dotyczącej innowacji, a także innowacji w przedsiębiorstwie uzdrowiskowym. Zwrócono uwagę na sposób zarządzania przedsiębiorstwem uzdrowiskowym i funkcjonowanie tego typu przedsiębiorstw w ramach lecznictwa uzdrowiskowego i turystyki uzdrowiskowej. Opisano czynniki, które determinują model biznesu w przedsiębiorstwie uzdrowiskowym. Wykazano, że dla dużej części uzdrowisk klientem jest instytucja finansująca, a nie kuracjusz. Zauważono, że w tych uzdrowiskach, gdzie klientem jest kuracjusz, w dużo większym stopniu zaobserwować można innowacje. Cel artykułu to wskazanie specyfiki innowacji w przedsiębiorstwie uzdrowiskowym. W artykule przedstawiono źródła, bariery i przykłady innowacji w przedsiębiorstwach uzdrowiskowych, a także obszary, które będą eksploatowane w następnych latach. Wskazano strukturę innowacji w przedsiębiorstwie uzdrowiskowym. Omówiono również najbardziej charakterystyczne innowacje, które wprowadzono w przedsiębiorstwach uzdrowiskowych na Dolnym Śląsku, podnosząc przy tym zaangażowanie samorządu województwa dolnośląskiego w rozwój dolnośląskiego zagłębia uzdrowiskowego.

\begin{abstract}
The article presents the potential and directions of functioning of spa enterprises. A review of the existing literature in relation to innovation, as well as innovation in the spa business was carried out. Attention is paid to the management of the spa enterprise and its functioning as part of spa treatment and spa tourism. Factors and their interdependencies are described, which determine the business model in a spa enterprise. It has been shown that for a large part of spas, the client is a financing institution, not a guest. It was noticed that in these spas, where the client is a bather, innovations can be observed to a much greater extent. The purpose of the article is to indicate the specificity of innovation in a spa enterprise. The article presents sources, barriers and examples of innovations in spa enterprises, as well as areas that will be exploited in the following years. The structure of innovation in a spa enterprise was indicated. The most characteristic innovations introduced in spa enterprises in Lower Silesia were also discussed, raising the involvement of the Śląskie voivodeship regional self-government in the development of the Lower Silesian spa basin.
\end{abstract}

Słowa kluczowe: dolnośląskie innowacje w przedsiębiorstwach uzdrowiskowych; innowacje; innowacje w przedsiębiorstwie uzrowiskowym; zarządzanie przedsiębiorstwem uzdrowiskowym

Keywords: innovations; innovations in a spa enterprise; Lower Silesian innovations in spa enterprises; management of a spa enterprise 
Otrzymano: 27 grudnia 2017

Received: 27 December 2017

Zaakceptowano: 11 czerwca 2018

Accepted: 11 June 2018

Sugerowana cytacja/Suggested citation:

Tutaj, J. (2018). Innowacje w przedsiębiorstwie uzdrowiskowym. Przedsiębiorczość - Edukacja [Entrepreneurship - Education], 14, 345-358. DOI: 10.24917/20833296.14.25

\section{Wstęp}

Innowacja to obecnie słowo-klucz do postępu i rozwoju. Innowacje są motorem budowania przewag konkurencyjnych przedsiębiorstw (Janasz, 2014). Jednak tworzenie nowych produktów i procesów, czy ulepszanie już istniejących to zjawisko obserwowane od stuleci. Dopiero jednak od XX w. człowiek podejmuje systematyczne badania nad procesami innowacyjnymi (OECD/Eurostat, 2006). Obszarem poszukiwań czynników odpowiedzialnych za innowacje są m.in. ogólnie rozumiana kultura, wychowanie, mentalność, a także kultura organizacyjna czy modele biznesu. Badania prowadzone są pod kątem poziomu i zakresu innowacji przez poszczególne sektory i pojedyncze podmioty. Ciekawym polem obserwacji działań innowacyjnych są przedsiębiorstwa uzdrowiskowe zlokalizowane w Polsce. Jest tak po pierwsze dlatego, że jeszcze kilka lat temu zdecydowana większość z nich należała do Skarbu Państwa, zatem zmiany własnościowe były stymulatorami działań innowacyjnych. Po drugie, zachodząca wciąż zmiana struktury klientów uzdrowisk, pojawiający się w nich w coraz większym procencie klient komercyjny, wymusza szereg przedsięwzięć innowacyjnych. Po trzecie, wszystkie konsekwencje trzeciej fali społeczeństwa, które kształtowane jest przez komputer i Internet, przez m.in. pojawiający się nowy kanał dystrybucji i nowe modele promocji w obu przypadkach funkcjonujące w przestrzeni wirtualnej również wpływają na konieczność pojawienia się w przedsiębiorstwie uzdrowiskowym nowych pomysłów i rozwiązań. Po czwarte, coraz większa konkurencja - w tym również rynku globalnego - na rynku turystycznym zmusza przedsiębiorstwa do utrzymania lub wzrostu udziału w rynku przez innowacje. Rynek, jak podkreśla J. Berbeka (Berbeka, 2015), jest na tyle turbulentny i na tyle konkurencyjny, że aby się na nim utrzymać, śledzić, a nawet wyprzedzać pewne trendy, musi się oferować coś, co jest rozwiązaniem nowym, nierzadko niszowym. Wynika to, jak dodaje Berbeka, z coraz silniej występującej indywidualizacji produktów i relacji w turystyce (Berbeka, 2015). Zjawiska te obserwujemy coraz częściej w przedsiębiorstwach uzdrowiskowych, zwłaszcza z prywatnym kapitałem lub/i obsługujących przede wszystkim klientów komercyjnych (którzy sami płacą za swój pobyt, w odróżnieniu od klientów, za których płaci Narodowy Fundusz Zdrowia lub Zakład Ubezpieczeń Społecznych).

Zarządzanie przedsiębiorstwem uzdrowiskowym to przede wszystkim utrzymanie właściwej harmonii między potrzebami klienta, które często są kształtowane przez same przedsiębiorstwa, a otoczeniem bliższym - efektywna współpraca z lokalną władzą, np. w zakresie inwestycji w infrastrukturę uzdrowiskową czy turystyczną danej miejscowości - oraz otoczeniem dalszym - przede wszystkim dobre relacje z Narodowym Funduszem Zdrowia, czy umiejętne czytanie konkurencji, rozwiązań finansowo-prawnych i warunków postulowanych przez środowisko medyczne. Zarządzanie przedsiębiorstwem 
uzdrowiskowym to zatem identyfikacja problemów klienta, analiza możliwych rozwiązań danych problemów i rozwiązanie problemów jako przykład nowoczesnego modelu biznesowego, gdzie najważniejsza jest wartość dla klienta. Współczesne zarządzanie to usprawnianie obsługi kuracjuszy, kształtowanie relacji z kuracjuszami, ulepszanie kanałów komunikacji, dystrybucji i sprzedaży, a także digitalizacja obsługi klienta (Tutaj, 2018).

W Polsce przez dziesięciolecia funkcjonował model kuracjusza przyjeżdżającego do sanatorium na rehabilitację ze skierowaniem z NFZ-etu lub ZUS-u. Proces prywatyzacji sprawił, że od kilku lat, ze zmienną dynamiką, w części podmiotów uzdrowiskowych obserwujemy zjawiska rynkowe we wzajemnie przenikających się obszarach: turystyki uzdrowiskowej oraz lecznictwa uzdrowiskowego. Klient staje się punktem odniesienia dla decyzji biznesowych, zwłaszcza w tych podmiotach, gdzie klient komercyjny stanowi znaczącą część w strukturze sprzedaży.

Zastosowanie strategii opartej na innowacjach wpływa dodatnio na realizację dwóch podstawowych celów organizacji: przetrwania i rozwoju. Przedsiębiorstwo innowacyjne cechuje zdolność do ciągłego poszukiwania nowych, oryginalnych rozwiązań, zarówno w obszarze technologicznym, jak i nietechnologicznym (Zakrzewska-Bielawska, 2012). Przedsiębiorstwo innowacyjne potrafi nie tylko stworzyć nowy, ulepszony produkt, nową metodę marketingową, ale też wdrożyć nowe rozwiązania. W idealnym modelu można znaleźć również umiejętność organizacji do zatrzymywania wartości z innowacji (Najda-Janoszka, 2013), np.: prawa ochrony intelektualnej i wynikające z nich możliwości sprzedaży licencji lub roszczenia w stosunku do podmiotów używających naszych rozwiązań. Taki kierunek modelu przedsiębiorstwa innowacyjnego powinien wyznaczać rozwój przedsiębiorstw uzdrowiskowych. Ostatnie dekady przyniosły ze sobą okres bezprecedensowych zmian. Obecnie tempo zmian jest tak wielkie, że firmy mają do czynienia praktycznie z ciągłą zmianą na rynku, a przetrwanie zależy od umiejętności szybkiego reagowania, co podkreśla m.in. Liz Clarke (Clarke, 1997). Jak pokazują dane, średni cykl życia firmy uległ radykalnemu skróceniu, tak samo jak cykl życia produktu. Stworzenie nowego, udoskonalonego procesu organizacyjnego, ulepszenie lub stworzenie nowych rozwiązań procesów technologicznych, czy też ciągłe zmiany w swojej palecie produktów to konieczność również dla przedsiębiorstw uzdrowiskowych.

\section{Pojęcie i wymiar innowacji}

Termin „innowacje” wprowadził w 1911 r. J.A. Schumpeter (Schumpeter, 1960), który określił nim komercyjne lub przemysłowe zastosowanie czegoś nowego: produktu, procesu, metody produkcji, nowego rynku lub źródeł dostawy, nowej formy prowadzenia działalności gospodarczej (Mirek, 2014). W pierwszej połowie XX w. innowacje utożsamiano przede wszystkim z produkcją. W działalności usługowej upowszechnienie się innowacji można wiązać przede wszystkim z pojawieniem się technologii informacyjnych i komunikacyjnych, które miały szczególny wpływ na sferę turystyki. Innowacje w turystyce nie ograniczały się jednak do rewolucji informatycznej, ale badania innowacji w turystyce znajdują się w początkowej fazie (Mirek, 2014). W odniesieniu do usług można zastosować definicję innowacji z tzw. Oslo Manual, gdzie innowacja jest rozumiana jako wdrożenie nowego lub znacząco udoskonalonego produktu, procesu, nowej metody marketingowej albo nowej metody organizacji. Jak zauważa J. Mirek, złożoność działalności turystycznej, w tym uzdrowiskowej, związana jest z jednoczesnością produkcji i konsumpcji (Mirek, 
2014). Usługi turystyczne można zaliczyć do tzw. produktów systemowych, które zaspokajają określony zbiór potrzeb i oczekiwań ich nabywców, a nie jedną, łatwo identyfikowalną potrzebę (Mirek, 2014). Żabiński zauważa, że usługa systemowa może być w większym stopniu niż produkty materialne tworzona z udziałem klienta (Żabiński, 2014). W odniesieniu do turystyki Hjalager wyróżniła pięć rodzajów innowacji. Są to innowacje produktowe, procesowe, menadżerskie, marketingowe i instytucjonalne (Hjalager, 2010). Warto również zauważyć, że z uwagi na niską kompleksowość nowych dóbr i usług turystycznych innowacje w turystyce narażone są na szybką, tanią i stosunkowo łatwą imitację przez inne przedmioty (Mursch, 2012). Za szczególny rodzaj innowacji można uznać zmianę modelu biznesu (Fuchs i in., 2006).

\section{Potencjał przedsiębiorstw uzdrowiskowych}

Lecznictwo uzdrowiskowe i powiązana z nim turystyka uzdrowiskowa mają dwa zasadnicze obszary rozwoju. Pierwszy z nich to odnowa sił biologicznych człowieka przez wykorzystanie wód leczniczych, kopalin naturalnych oraz właściwości klimatu. Obszar drugi to aktywne formy spędzania czasu wolnego (bliskość terenów górskich, leśnych oraz niewykorzystana baza sportowo-rekreacyjna). Około 40\% kuracjuszy leczy w polskich uzdrowiskach choroby reumatyczne, 20\% - dolegliwości układu oddechowego, $12 \%$ - dolegliwości układu krążenia, a 10\% - choroby przewodu pokarmowego. Większość uzdrowisk położona jest w pasie górskim i podgórskim oraz w terenie nadmorskim (Tutaj, 2017).

Uzdrowiska to nie tylko zaplecze sanatoryjne, które liczy ponad 45000 łóżek, ale także ogromna, licząca około 90000 miejsc baza turystyczna. Potencjał ten stanowi około $18 \%$ bazy turystycznej całego kraju. W ostatnim okresie odnotowujemy znaczny rozwój turystyki zdrowotnej. Często pojęcia turystyki zdrowotnej i turystyki uzdrowiskowej są wymieniane zastępczo. Jednak ich zakres terminologiczny nie pokrywa się w pełni. Pojęcie turystyki zdrowotnej jest pojęciem złożonym, pod którym rozumie się realizowanie celów zdrowotnych przez różne rodzaje turystyki: uzdrowiskowej, weekendowej, kwalifikowanej, pobytowej (Dec, 2014). Ten rodzaj turystyki jest coraz bardziej popularną formą spędzania wolnego czasu, co uwidacznia się we współczesnych trendach związanych z działalnością uzdrowisk, które w swojej ofercie uwzględniają już nie tylko lecznictwo uzdrowiskowe (Dec, 2014). W Europie już w latach 70. XX w. zaczęto stopniowo odchodzić od tradycyjnego rozwoju uzdrowisk opartego na lecznictwie, w kierunku nowoczesnych form turystyki zdrowotnej (Januszewska, 2005). Jednak cały czas podstawową formą turystyki zdrowotnej jest turystyka uzdrowiskowa. Medycyna uzdrowiskowa obejmuje całokształt działalności prowadzonej w uzdrowisku, ukierunkowana na świadczenia zdrowotne, obejmuje balneoterapię, klimatoterapię, fizykoterapię, balneochemię, mikrobiologię oraz geologię uzdrowiskową. Lecznictwo uzdrowiskowe odgrywa we współczesnej medycynie rolę wspomagającą i intensyfikującą inne metody leczenia zachowawczego i operacyjnego. Przyczynia się do wdrażania zasad profilaktyki, promowania zdrowia, usprawniania funkcji ustrojowych przez zwiększenie zdolności do samoobrony organizmu. Pełni również funkcję rehabilitacyjną w zakresie chorób układu ruchu oraz kardiologii (Ponikowska, 2007). Czynniki wpływające na konkurencyjność turystyki uzdrowiskowej według Mirek to budowa i modernizacja infrastruktury, estetyka i rewitalizacja parków zdrojowych, pijalni, działania marketingowe - a w szczególności 
tworzenie markowego produktu, międzynarodowa rozpoznawalność uzdrowiska, innowacje, udostępnienie turystom i kuracjuszom urządzeń pasywnego i aktywnego odprężenia, ulgi podatkowe (Mursch, 2016).

Uzdrowiska to polski produkt markowy, za czym przemawiają walory przyrodnicze, znacząca liczba miejscowości uzdrowiskowych (Komornicki, 2015), a także wielowiekowa tradycja w świadczeniu usług uzdrowiskowych. Turystyka uzdrowiskowa i lecznictwo uzdrowiskowe oparte są na funkcjonowaniu gmin uzdrowiskowych oraz przedsiębiorstw uzdrowiskowych. W Polsce działa kilkaset przedsiębiorstw uzdrowiskowych. Większość z nich to podmioty prywatne. Jednak cały czas większość łóżek, a więc większa część rynku, jest w rękach przedsiębiorstw, których właścicielem jest Skarb Państwa, spółka Skarbu Państwa lub jednostka samorządu terytorialnego. Dla przykładu, na obszarze Dolnego Śląska możemy zaobserwować trzy grupy właścicielskie uzdrowisk. Największa skupiona jest w Polskiej Grupie Uzdrowisk należącej do portfela TFI KGHM. Skupia ona Uzdrowiska Kłodzkie w Polanicy-Zdroju, Dusznikach-Zdroju i Kudowie-Zdroju, a także w Świeradowie, Czerniawie i Cieplicach (poza Dolnym Śląskiem w Połczynie-Zdroju). Druga co do wielkości grupa to uzdrowiska należące do samorządu województwa: Lądek-Długopole, Szczawno-Jedlina oraz Sanatoria Dolnośląskie (w Rościszowie, Sokołowsku, Dusznikach, Kudowie i Szczawnie Zdroju). Najmniejszą grupę stanowią właściciele prywatni: Polski Holding Medyczny PCZ i jego uzdrowisko w Przerzeczynie.

Przez przedsiębiorstwo uzdrowiskowe należy rozumieć taki podmiot prawa handlowego, który prowadzi swoją działalność na terenie miejscowości uzdrowiskowej oraz oferuje zabiegi w zakresie fizjoterapii lub/i balneologii, a także używa terapii na bazie naturalnych tworzyw lub jest jednostką lecznictwa uzdrowiskowego. Zarządzanie przedsiębiorstwem uzdrowiskowym powinno być oparte na orientacji humanistycznej, co samo w sobie w wielu podmiotach będzie swoistą innowacją. W poszukiwaniu korzeni zarządzania humanistycznego sięga się do koncepcji, w której nadrzędnym celem jest dobro człowieka (Rąb, 2015). Podstawowe założenia, na których opiera się humanistyczna koncepcja organizacji, obejmują: postrzeganie organizacji jako grupy ludzi, którzy jako członkowie danej społeczności przyjmują za główny cel organizacji dobrostan swój i społeczności, w której obrębie organizacja działa, oraz ujmowanie zarządzania jako ludzkiej praktyki, której celem jest doprowadzenie do jak najlepszego funkcjonowania danej organizacji.

Zarządzanie przedsiębiorstwem uzdrowiskowym zdeterminowane jest sposobem zdobywania przychodów. Ponad 50\% przedsiębiorstw uzdrowiskowych w Polsce opłacanych jest przez NFZ i ZUS (Mazur, 2017). Piotr Komornicki wskazuje, że problemem jest masowy klient usług uzdrowiskowych, a nie pojedynczy kuracjusz czy pacjent, tylko państwowy płatnik (Komornicki, 2015). Przedsiębiorstwa uzdrowiskowe uczestniczą w łańcuchu redystrybucji środków budżetowych i są w moim przekonaniu quasi jednostkami budżetowymi. Dlatego zauważamy dużo wolniejszy niż w innych sektorach proces urynkowienia się branży, a w tym procesów digitalizacyjnych. Celem dla zarządzających przedsiębiorstwem uzdrowiskowym jest zdobycie, powiększenie lub utrzymanie kontraktów z NFZ-em i ZUS-em. Klient nie jest najważniejszym wyzwaniem dla zarządzających, mimo tworzonych misji, wizji i sloganów marketingowych. Co prawda NFZ i ZUS wskazują na wymogi, w imieniu klienta, ale jednak przez własne kryteria i własną politykę. Ponadto przedsiębiorstwa systematycznie zwiększają procentowy udział klientów komercyjnych w puli swoich przychodów. W Polsce funkcjonują również przedsiębiorstwa 
uzdrowiskowe oparte w 100\% na kliencie komercyjnym (najczęściej prywatne), jednak ich udział w rynku nie przekracza 16\% (GUS, 2016). Zarzadzanie przedsiębiorstwem uzdrowiskowym zdeterminowane jest czteroma głównymi czynnikami: państwowym płatnikiem (NFZ-etem, ZUS-em), rzeczywistymi klientami (którymi stali się klienci opłacani oraz klienci komercyjni), grupami zawodowymi (zwłaszcza biały personel - lekarze, związki) oraz polityką właściciela. Politykę właściciela wymieniam na czwartym miejscu nieprzypadkowo. Łatwo odczytać znaczenie przedsiębiorstw uzdrowiskowych dla właściciela, które jest trzecio-, czy czwartorzędne, przez lekturę sprawozdań, uchwał jednostek samorządu terytorialnego czy spółek Skarbu Państwu - które dominują w strukturze własnościowej przedsiębiorstw uzdrowiskowych. W znaczący sposób funkcjonowanie przedsiębiorstwa uzdrowiskowego jest determinowane przez politykę państwa, regionalne priorytety i tzw. klienta formalnego - które to czynniki występują w działaniach zarówno Narodowego Funduszu Zdrowia, jak i Zakładu Ubezpieczeń Społecznych. W ciągle niewystarczający sposób wpływ na funkcjonowanie przedsiębiorstw uzdrowiskowych ma klient. Przykładami tego są sporadyczne, rzadkie badania potrzeb klientów czy trwałe relacje z klientami.

\section{Innowacje w przedsiębiorstwach uzdrowiskowych}

Innowacyjność przedsiębiorstw, w tym uzdrowiskowych jest nie tylko kluczem do osiągnięcia przez nie sukcesu, ale coraz częściej warunkiem ich dalszego funkcjonowania na rynku. Przedsiębiorstwo uzdrowiskowe na podstawie nowych możliwości wykorzystania własnego potencjału, a także przez reakcje na zmiany otoczenia, szczególnie rynkowego, powinno swoje nowe rozwiązania konfrontować, podczas i po ich wdrożeniu, z pomiarem zadowolenia swojego klienta. Źródłem innowacji w przedsiębiorstwie uzdrowiskowym są w moim przekonaniu przede wszystkim zapożyczenia $\mathrm{z}$ innych uzdrowisk, $\mathrm{z}$ innych podmiotów działających na polskich i zagranicznych rynkach. W następnej kolejności należy wymienić proces ulepszeń, a także zewnętrzne środki finansowe, które skłaniają do działań innowacyjnych (np.: Program Operacyjny Inteligentny Rozwój, którego instytucją pośredniczącą jest NCBR). Ponadto czynnikami stymulującymi powstawanie innowacji są: rezultaty współpracy, w tym współpracy z nauką, a także standaryzacja procesowa i produktowa. Głównym powodem potrzeby tworzenia innowacji, którą możemy przywołać z literatury, jest zmienność w czasie motywacji osób przyjeżdżających do uzdrowisk. Motywy podejmowania podróży do uzdrowisk są inspiracją dla tworzenia nowych produktów turystycznych, nowych sposobów komunikowania się, dystrybuowania tychże komunikatów (Dryglas, 2009). Można wyróżnić co najmniej cztery obszary, w których powstają innowacje w turystyce uzdrowiskowej. Są to obszary produktowe, np. opatrunek kolagenowy; procesowe, np. nowy sprzęt i aparatura medyczna, organizacyjne, np. elektroniczne rezerwacje, marketingowe, np. programy lojalnościowe. Zmiany innowacyjne, które są zauważalne w lecznictwie uzdrowiskowym, to poprawa jakości zarządzania, poprawa jakości, rozwój świadczeń niemedycznych, poprawa efektywności terapii, poprawa bezpieczeństwa chorych i personelu, zwiększenie komfortu wykonywania zabiegów, zmniejszenie kosztów eksploatacyjnych, leczenie chorób: kardiologicznych i angiologicznych, układu ruchu, metabolicznych, pulmonologicznych, chorób wieku podeszłego, chorób nowotworowych, chorób psychicznych (Ponikowska, 2007). Dodatkowo wiele uzdrowisk wprowadza nowe technologie terapeutyczne,np.: krioterapię 
ogólnoustrojową, ciepłolecznictwo ogólne wykorzystujące promieniowanie IR, hiperbarię, fotodynamikę, biofotanikę (Januszewska, Nawrocka, 2009). Celem działalności innowacyjnej w przedsiębiorstwie uzdrowiskowym jest przede wszystkim poprawa jakości i zwiększenie ilościowej oferty dla klienta (Piotrowska, 2014), zwiększenie przychodów, zmniejszenie kosztów, realizacja wytycznych, sugestii właściciela lub klientów.

Tab. 1. Innowacje w przedsiębiorstwie uzdrowiskowym

\begin{tabular}{|c|c|}
\hline Innowacje & Przykłady innowacji \\
\hline produktowe & $\begin{array}{l}\text { - pakiety lecznicze } \\
\text { - zabiegi wellnes \& spa } \\
\text { - produkty zdrojowe - kosmetyki } \\
\text { - opatrunek kolagenowy } \\
\text { - innowacyjne zabiegi - oczyszczające, peelingujące, detoksykujące, } \\
\text { wyszczuplające, ujędrniające, regenerujące czy np. radonoterapia } \\
\text { - dostęp do room service } \\
\text { - diagnostyka } \\
\text { - gry planszowe dla dzieci z motywami uzdrowiska } \\
\text { - inne zastosowanie tworzyw naturalnych } \\
\text { - konsultacje z najlepszymi specjalistami }\end{array}$ \\
\hline procesowe & $\begin{array}{l}\text { - nowy sprzęt i aparatura medyczna } \\
\text { - nowe oprogramowanie } \\
\text { - skracanie procesu leczenia } \\
\text { - skracanie kolejek } \\
\text { - e-sklep } \\
\text { - szybsze przygotowywanie posiłków }\end{array}$ \\
\hline organizacyjne & $\begin{array}{l}\text { - proces prywatyzacji, zmiany własnościowe } \\
\text { - tworzenie w strukturach ośrodków badawczo-rozwojowych } \\
\text { - tworzenie zespołów kreatywnych } \\
\text { - elektroniczny obieg dokumentów i bazy danych klientów } \\
\text { - elektroniczne rezerwacje } \\
\text { - wprowadzanie systemów motywacyjnych dla pracowników } \\
\text { - e-marketer } \\
\text { - wyjazdy i przyjazdy tego samego dnia }\end{array}$ \\
\hline marketingowe & $\begin{array}{l}\text { - podtrzymywanie kontaktu z klientami po usłudze } \\
\text { - programy lojalnościowe } \\
\text { - karty rabatowe } \\
\text { - nowe kanały dystrybucji }\end{array}$ \\
\hline
\end{tabular}

Źródło: opracowanie własne

Przedsiębiorstwa uzdrowiskowe w Polsce to w dużej części wciąż niewykorzystany potencjał zarówno z punktu widzenia makro - państwa - jako dostarczyciele podatków ze zwiększających się przychodów, jak również z punktu widzenia mikro - efektywnie zarządzanej organizacji. Czynniki hamujące rozwój przedsiębiorstw uzdrowiskowych to przede wszystkim: słabość właściciela (brak zainteresowania, pomysłu, konsekwencji, a także finansów), słabość kadry zarządzającej i pracowników (przyzwyczajenia, wykształcenie, mentalność, roszczeniowość), dyktat białego personelu (zwłaszcza lekarzy, którzy rzadko integrują się z podmiotem i na pierwszy plan wysuwają swoje partykularne interesy), a także monopol Narodowego Funduszu Zdrowia i Zakładu Ubezpieczeń Społecznych jako płatników, niekorzystne dla rozwiązań rynkowych zapisy prawne (z 28 
lipca 2005 r.), brak rzeczywistej współpracy pomiędzy podmiotami oraz nieprzystosowany do rynku, funkcjonujący w przedsiębiorstwach uzdrowiskowych model biznesu oddalony od klienta (przez płatników państwowych, lobby pracownicze i brak świadomości zasad rynkowych). Czynniki negatywnie wpływające na powstawanie innowacji w przedsiębiorstwach uzdrowiskowych to: brak wolnej przestrzeni dla dyskusji, wymiany myśli i pomysłów, brak systematycznych spotkań, rzadka styczność przestrzenna pomiędzy pracownikami z różnych jednostek, słabo lub niefunkcjonujące systemy motywacyjne, niski poziom współpracy pomiędzy firmami, wysokie koszty innowacji, brak środków finansowych, niski poziom współpracy z nauką oraz współpracy między sobą, zachwiane proporcje pomiędzy białym personelem a częścią zarządczą i administracyjną, niski poziom integracji załogi, stosunkowo niski poziom satysfakcji z pracy wśród pracowników, podporządkowywanie się priorytetom zewnętrznym - wymogom NFZ-etu oraz sprawom bieżącym (Tutaj, 2018).

\section{Działania innowacyjne na przykładzie przedsiębiorstw uzdrowiskowych z Dolnego Śląska}

Dolny Śląsk to polskie zagłębie uzdrowiskowe - w tym regionie znajduje się najwięcej gmin i spółek uzdrowiskowych w naszym kraju (Gąsior, Szromek, 2012). Dlatego też w aktualnej Strategii rozwoju województwa dolnośląskiego znajduje się szereg zapisów, odnoszących się do konkretnych działań na rzecz rozwoju przemysłu uzdrowiskowego, co świadczy o roli, jaką chcą przypisać zarządzający województwem turystyce uzdrowiskowej. W Strategii rozwoju... wskazuje się na inwestycje w celu likwidacji lokalnych źródeł niskiej emisji, rewitalizacje zabytkowych obiektów uzdrowiskowych, budowę i modernizację sieci dróg, w tym kolejowych, do uzdrowisk, a także wspólne budowanie wizerunku regionu jako atrakcyjnego miejsca wypoczynku, otwartego na świat, o nieprzeciętnych walorach przyrodniczych, kulturowych i uzdrowiskowych (Urząd Wojewódzki...). Od kilku lat zaobserwować można szereg działań w poszczególnych przedsiębiorstwach na Dolnym Śląsku, które mają charakter innowacyjny. Przykładem może być wprowadzenie do oferty uzdrowiskowej w Cieplicach zabiegów w zakresie okulistyki, zwłaszcza leczenie zespołu suchego oka. Działania te spowodowały, że w Cieplickim kurorcie okulistyka stała się kluczowym profilem leczniczym. Innym przykładem jest lecznictwo uzdrowiskowe w zakresie kardiologii inwazyjnej, pobyty rehabilitacyjne bezpośrednio po dokonanej operacji oferowane przez Spółkę Szczawno-Jedlina, dzięki którym pacjenci do minimum skracają czas powrotu do pracy. Innowacyjnym projektem przygotowanym przez członka zarządu województwa dolnośląskiego odpowiedzialnego za rozwój regionalny w 2013 r. była koncepcja „Sudety-Zdrój”, oparta na kilkunastu filarach, m.in. na: uruchomieniu sukcesywnie prowadzonej rewitalizacji zarówno w miastach, jak i na wsiach; poprawie ładu przestrzennego i estetycznego, zwłaszcza w ośrodkach turystyczno-wypoczynkowych; maksymalizacji wykorzystania walorów uzdrowiskowych i koordynacji usług pomiędzy uzdrowiskami; poprawie dostępności wewnątrz obszaru i z autostrady A4 przez inwestowanie w budowę i modernizację sieci komunikacyjnej (np.: Droga Sudecka, Ring Sudecki - droga okalająca ze wszystkich stron: niemieckiej, czeskiej i polskiej Sudety, podkreślająca atrakcyjność tego obszaru); modernizacje połączeń kolejowych Wrocław - Wałbrzych - Jelenia Góra czy Kłodzko - Kudowa-Zdrój; rozbudowie infrastruktury rowerowej; adaptacji obiektów poprzemysłowych na cele turystyczne (Stara Kopalnia w Wałbrzychu); 
wykorzystaniu wód geotermalnych do celów uzdrowiskowych i turystycznych; wsparciu ośrodków kulturotwórczych w promowaniu turystyki i wykorzystaniu własnych potencjałów; budowie tożsamości lokalnej i aktywizacji działalności gospodarczej; kreowaniu jednolitego wizerunku i silnej marki - opartej na istniejących i nowych produktach turystycznych; utrwalaniu pozytywnego odbioru południa Dolnego Śląska. Koncepcja „Sudety-Zdrój” od dwóch lat jest wdrażana w życie (Sudety-Zdrój, 2013).

Najczęstszą pozycją występującą w strategiach rozwoju przedsiębiorstw uzdrowiskowych na Dolnym Śląsku jest poprawa bazy noclegowej przez modernizację dotychczasowej bazy oraz budowę nowej. Największe projekty inwestycyjne w poszczególnych przedsiębiorstwach to między innymi: Cieplice - Długi Dom, Świeradów-Zdrój - Dom Zdrojowy, Kudowa-Zdrój - Polonia. Największym projektem w Sanatoriach Dolnośląskich, który był realizowany zgodnie z przyjętą Strategią rozwoju..., była modernizacja obiektu Biały Orzeł w Sokołowsku, w którym utworzono Dom Opieki Długoterminowej dla osób starszych. W obiekcie znajduje się ponad 100 miejsc noclegowych z najnowocześniejszym wyposażeniem socjalnym i zabiegowym. Inwestycja kosztowała ponad $8 \mathrm{mln}$ zł i była dofinansowana z Regionalnego Programu Operacyjnego dla Województwa Dolnośląskiego w wysokości blisko $6 \mathrm{mln}$ zł. Innym przykładem innowacji inwestycyjnej jest modernizacja domu Waligóra w Sokołowsku, sfinansowana z mechanizmu norweskiego w kwocie 6 mln zł, i zlokalizowanie tam zakładu przyrodoleczniczego. Sztandarowym projektem w Spółce Szczawno-Jedlina była modernizacja Domu Zdrojowego, którego koszt przekroczył 6 mln zł i był prawie w całości pokryty z komercyjnego kredytu inwestycyjnego. Inwestycja została zrealizowana w celu podniesienia standardu usług i została zakończona. W Spółce Lądek-Długopole wymienić należy dwa projekty, którymi są: modernizacja Szpitala Uzdrowiskowego Dąbrówka za ponad $3 \mathrm{mln}$ zł - ze wsparciem środków europejskich - oraz modernizacja obiektu Wojciech. Obie inwestycje ukończono. Inwestycją w Przerzeczynie jest budowa kompleksu zdrojowego ze szpitalem dla około 400 osób, której koszt oscyluje wokół $25 \mathrm{mln}$ zł. Flagowym projektem dla Cieplic jest rozbudowa Domu Zdrojowego o bazę noclegową - kolejnych 200 miejsc - oraz zakład przyrodoleczniczy na kwotę ponad $40 \mathrm{mln}$ zł. W Świeradowie największą inwestycją ma być obiekt Borowina na ponad 300 osób z pełnym zapleczem zabiegowym, utworzony za ok. 80 mln zł. W Polanicy-Zdroju flagowym, zakończonym projektem jest modernizacja Wielkiej Pieniawy na poziomie ponad 30 mln zł. Ogólnie w latach 2010-2016 w dolnośląskich uzdrowiskach zrealizowano inwestycje na ponad $200 \mathrm{mln}$ zł. Plany rozwojowe na najbliższe lata zakładają wydatki na poziomie ponad $500 \mathrm{mln}$ zł. To najlepiej świadczy o potencjale i witalności tej branży oraz jej pozycji w regionie.

Innym przykładem projektu jest utworzenie Dolnośląskiego Centrum Diagnostyki i Terapii Osteoporozy w Lądku-Zdroju, które jako jedyne w Polsce oferuje kompleksowe i profesjonalne diagnozowanie oraz leczenie osteoporozy. Znajdująca się w nim pracownia densytometryczna została wyposażona w innowacyjny sprzęt medyczny, m.in. w najnowszej generacji aparat Discovery Wi Hologic do badania gęstości mineralnej kości, który wykonuje pełny zakres badań densytometrycznych z innowacyjną oceną mikroarchitektury kości (badanie TBS) oraz badanie morfometryczne wykrywające złamania osteoporotyczne kręgosłupa. W Centrum działa też poradnia leczenia osteoporozy, która zapewnia porady lekarzy reumatologów i internistów oraz specjalistyczny program rehabilitacyjny dla pacjentów z rozpoznaną osteoporozą lub czynnikami ryzyka tej choroby, który prowadzony jest w oparciu o stosowane w Lądku-Zdroju nowoczesne metody 
kinezyterapii (ćwiczenia z oporem elastycznym i wykorzystaniem metody biofeedback, treningi na platformach dynamograficznych) oraz tradycyjne metody balneologiczne wykorzystujące korzystne działanie na metabolizm kostny radonu i fluoru zawartego w lądeckich termalnych wodach radonowo-siarczkowo-fluorkowych (Wielokulturowy kurort..., 2016).

Jeszcze innym przykładem jest pozyskiwanie klientów przez kontakty z uniwersytetami trzeciego wieku na Dolnym Śląsku, specjalne oferty pobytowe i przyjazdy promocyjne połączone z prezentacją oferty ${ }^{1}$. Bardzo ciekawym przykładem aktywności innowacyjnej na Dolnym Śląsku są zespoły kreatywne. Zespół kreatywny tworzą pracownicy różnych pionów, działów, stanowisk, z różnym doświadczeniem i wykształceniem. Zespoły mają większą siłę tworzenia nowych pomysłów i rozwoju ludzi utalentowanych, lepszą orientację na klienta, wpływają na wzrost satysfakcji pracowników oraz na podejmowanie przez nich trafniejszych decyzji. Przed zespołami kreatywnymi postawiono cele i określono dla nich działania, którymi są: projektowanie, odkrywanie, wynajdywanie, porządkowanie, przewidywanie, planowanie, poszukiwane nowych kierunków rozwoju, a także udoskonalanie dotychczasowych procesów oraz finalnych produktów i usług. Uznano, że prace Zespołu powinny pomagać pracownikom w wykazywaniu aktywności i tendencji do innowacyjnych rozwiązań, powinny niwelować postawy autorytarne, motywować do ciągłego poszukiwania i poprawiania, stymulować klimat do dyskusji nad pomysłami, a wcześniej uwagami, ostatecznie tworzyć pewną matryce, w której na pierwszym miejscu jest nowe, a nie stare. Dobór pracowników do zespołu kreatywnego oparto na różnorodności: różnych stylach poznawczych, punktach widzenia, poziomie wiedzy, umiejętnościach technicznych, różnych działach i stanowiskach. Praca zespołu kreatywnego odbywa się z wykorzystaniem technik wspomagających pracę $\mathrm{w}$ zespole, nie tylko z zastosowaniem burzy mózgów, ale też diagramu Ishikawy, kruszenia, mapy myśl, zbieraniu pomysłów oraz idei. Członkowie zespołu po pierwszych spotkaniach w miejsce każdego starego założenia tworzą nowe, a dalej na tej podstawie powstaje nowe rozwiązanie ${ }^{2}$.

Ostatnio wdrożonym przykładem innowacji organizacyjnej jest utworzenie w $2018 \mathrm{r}$. w strukturach Spółki Lądek-Długopole ośrodka badawczo rozwojowego. Celem powołanego ośrodka jest specjalizacja Spółki Uzdrowisko Lądek-Długopole, standaryzacja w lecznictwie uzdrowiskowym, podniesienie poziomu bezpieczeństwa w procesie leczenia, prowadzenie systematycznych badań w zakresie poziomu satysfakcji wśród kuracjuszy, pracowników i traktowanie ich jako źródła do wprowadzania ulepszeń i zmian, przygotowywanie i wdrażanie projektów badawczych w zakresie lecznictwa uzdrowiskowego, modernizacja obiektów Jerzy i Wojciech, integrowanie środowiska balneologicznego i fizjoterapeutycznego na Dolnym Śląsku oraz systematyczna współpraca z jednostkami naukowymi, działalność innowacyjna $\mathrm{w}$ obszarze promocji zdrowia i lecznictwa uzdrowiskowego ${ }^{3}$.

\footnotetext{
${ }^{1}$ Wywiad z kierownikiem Działu Sprzedaży Spółki Uzdrowiskowej Lądek-Długopole, Iwoną Sobolewską, przeprowadzony w dniu 12 września $2016 \mathrm{r}$.

${ }^{2}$ Sprawozdania ze spotkań Zespołu Kreatywnego w Spółce Uzdrowiskowej Lądek-Długopole w roku 2016 - dokumenty wewnętrzne.

${ }^{3}$ Plany i cele Ośrodka Badawczo Rozwojowego w Lądku Zdroju - dokument wewnętrzny Spółki.
} 


\section{Podsumowanie}

Należy prognozować w następnych latach działania innowacyjne w przedsiębiorstwach uzdrowiskowych w tworzeniu projektów: Smart Medical City, które w modelowy sposób mogą wyznaczyć nową jakość w tworzeniu planów rozwojowych uzdrowisk, w oparciu o współpracę pomiędzy wszystkimi podmiotami funkcjonującymi w danej miejscowości uzdrowiskowej, na czele z władzą samorządową. Celem takich projektów jest budowa i wdrożenie spójnych, kompleksowych rozwiązań informatycznych, które przyczynią się do podniesienia poziomu jakości udzielanych świadczeń zdrowotnych i opieki nad kuracjuszem oraz zwiększenia konkurencyjności oferty medycznej i atrakcyjności obszaru uzdrowiskowego miejscowości. Tworzenie klastrów, ściślejsza współpraca to kolejny obszar, który zostanie wykorzystany przez innowacyjne zespoły. Wydaje się, że w ramach innowacji inwestycyjnych będą następować znacząco większe inwestycje w Zakłady Przyrodolecznicze, które są sercem uzdrowiska. Dalej znaczący rozwój będzie związany Z wellnes \& spa. Nowy segment zdrowych, młodych, aktywnych klientów wymusi większy nacisk na profilaktykę i promocję zdrowia, a także większy zakres diagnostyki. Należy pamiętać o konieczności wprowadzenia odpowiedniej kategoryzacji w zakresie usług uzdrowiskowych, tak aby koszty i jakość leczenia mogły być uzależnione od standardów samych uzdrowisk i ich bazy leczniczej. Kategoryzacja w postaci gwiazdkowej powinna objąć zarówno całe uzdrowiska w zależności od jakości usług, jak również poszczególne obiekty sanatoryjno-hotelarskie i inne usługowe obiekty lecznicze. Działalność przedsiębiorstw uzdrowiskowych wpisuje się w filozofię życia zmierzającą do bycia zdrowym, prowadzenia zdrowego trybu życia i posiadania atrakcyjnego wyglądu. Po analizie wielu materiałów z kongresów balneologicznych i medycyny fizykalnej, seminariów, konferencji w zakresie medycyny uzdrowiskowej, a także wystąpień osób zarządzających spółkami wydaje się, że w najbliższych latach będziemy mogli spodziewać się dalszego rozwoju działań innowacyjnych w zakresie wyjazdów krótkoterminowych, w bliskiej odległości do $120 \mathrm{~km}$, dla osób aktywnych, chcących jak najdłużej zachować sprawność, oraz nowych produktów dla osób starszych - łącznie z rozwiązaniami wyjazdowymi do klienta/ klientów do większych ośrodków miejskich, a także nowych ofert i sposobów dotarcia do rosnącej grupy docelowej, nastawionej na zdrowy styl życia.

\section{Literatura}

References

Berbeka, J., Borodako, K., Rudnicki, M. (2015). Postrzeganie innowacji w branży spotkań przez przedstawicieli krakowskich PCO. Zeszyty Naukowe Uniwersytetu Ekonomicznego w Krakowie, 40, 5-17.

Boruszczak, M. (2011). Turystyka zdrowotna i uzdrowiskowa, Gdańsk: Wyższa Szkoła Turystyki i Hotelarstwa w Gdańsku.

Clarke, L. (1997). Zarządzanie zmianą, Warszawa: Gebethner i Spółka.

Dąbrowska, B. (2006). Innowacje w usługach a sukces rynkowy. Trendy rozwojowe usług turystycznych w warunkach globalizacji. W: Turystyka w badaniach naukowych. Rzeszów: Wyższa Szkoła Informatyki i Zarządzania w Rzeszowie, 120-123.

Dryglas, D. (2009). Innowacje produktowe turystyki uzdrowiskowej. W: Innowacyjne kierunki rozwoju turystyki uzdrowiskowej w lecznictwie uzdrowiskowym. Muszyna: VII Kongres Uzdrowisk Polskich, Stowarzyszenie Gmin Uzdrowiskowych RP. 
Dryglas, D. (2007). Innowacje produktowe turystyki uzdrowiskowej. W: Innowacyjne kierunki rozwoju turystyki uzdrowiskowej. Muszyna: VIII Kongres Uzdrowisk Polskich, Stowarzyszenie Gmin Uzdrowiskowych RP.

Dryglas, D. (2006). Kształtowanie produktu turystycznego uzdrowisk w Polsce. Kraków: Wydawnictwo Uniwersytetu Jagiellońskiego.

Fuchs, K., Kossut, N., Rudolf, T., Workiewicz, M., Wróblewski, J. (2006). Strategie innowacji, E-mentor. Gąsior, I., Szromek, A. (2012). Historyczny kontekst działalności uzdrowiskowej w Polsce. W: A. Szromek (red.), Uzdrowiska i ich funkcja turystyczno-lecznicza. Kraków.

Golba, J. (2015). Uzdrowiska Polskie - wyzwania i szanse. Inowrocław: Stowarzyszenie Gmin Uzdrowiskowych RP.

Golba, J. (2002). Aktywizacja społeczno-gospodarcza gmin uzdrowiskowych jako podstawa zahamowania wzrostu bezrobocia, a w konsekwencji docelowego generowania miejsc pracy. Krynica.

Golba, J. (2001a). Uwarunkowania prawne i finansowe uzdrowisk polskich. Biuletyn Stowarzyszenia Gmin Uzdrowiskowych RP, 1-2, 56-64.

Golba, J. (2001b). Analiza aktualnej sytuacji prawnej uzdrowisk polskich. Biuletyn Stowarzyszenia Gmin Uzdrowiskowych RP, 3, 23-31.

Golba, J. (2000). Przyszłość uzdrowiska Krynica w aspekcie zmian polityczno-gospodarczych kraju. Krynica.

Golba, J.(1993). Ekonomiczne podstawy funkcjonowania gmin uzdrowiskowych. Biuletyn Stowarzyszenia Gmin Uzdrowiskowych RP, 1, 33-39.

Górniak, J., Mazur, S. (red.). (2012). Zarządzanie strategiczne rozwojem. Warszawa: Ministerstwo Rozwoju Regionalnego.

Iwanek, T. (2006). Turystyka uzdrowiskowa w gospodarce regionu i kraju. Wrocław: Wydawnictwo Wyższej Szkoły Zarządzania we Wrocławiu.

Janasz, W., Kozioł-Nadolna, K. (2011). Innowacje w organizacji. Warszawa: Polskie Wydawnictwo Ekonomiczne.

Januszewska, M. (2005). Perspektywy rozwoju uzdrowisk w Polsce. Turystyka i Rekreacja

Januszewska, M., Nawrocka, E. (2009). Wpływ wiedzy na innowacyjność przedsiębiorstw uzdrowiskowych. W: Innowacyjne kierunki rozwoju turystyki uzdrowiskowej w lecznictwa uzdrowiskowego. Muszyna: VIII Kongres Uzdrowisk Polskich, Stowarzyszenie Gmin Uzdrowiskowych RP.

Jaremen, D., Rapacz, A. (2009). Innowacje w percepcji przedstawicieli jednostek samorządu terytorialnego i klientów uzdrowisk. W: Innowacyjne kierunki rozwoju turystyki uzdrowiskowej w lecznictwa uzdrowiskowego. Muszyna: VIII Kongres Uzdrowisk Polskich, Stowarzyszenie Gmin Uzdrowiskowych RP.

Komornicki, P. (2015). Uzdrowisko XXI wieku - innowacje w uzdrowiskach na przykładzie Uzdrowiska Iwonicz S.A. Kraków.

Krupski, R. (2013). Zarządzanie strategiczne, Wałbrzych: Wydawnictwo Wałbrzyskiej Wyższej Szkoły Zarzadzania i Przedsiębiorczości.

Mazur, B. (2017). Zarządzanie humanistyczne i ekonomiczne - przegląd stanowisk. W: L. Kiełtyki i P. Kobisa(red.), Wybrane zagadnienia zarzadzania wspótczesnymiprzedsiębiorcami. Częstochowa: Wydawnictwo Politechniki Częstochowskiej.

Madeyski, A. (1997). Problemy lecznictwa i turystyki w uzdrowiskach polskich. Problemy Turystyki, 1-4.

Madeyski, A. (1999). Szanse polskich uzdrowisk w warunkach gospodarki rynkowej. W: Materiały pokonferencyjne z I Międzynarodowej Konferencji Naukowej - Turystyka uzdrowiskowa - stan i perspektywy. Jastrzębia Góra.

Mirek, J. (2014). Innowacyjność jako czynnik funkcjonowania i rozwoju polskich uzdrowisk. Handel Wewnętrzny, 31(2), 82-98.

Mirek, J. (2013a). Organizacyjno-prawne aspekty lecznictwa uzdrowiskowego dzieci i młodzieży. Zeszyty Naukowe Uniwersytetu Szczecińskiego, Ekonomiczne Problemy Turystyki, 43-58. 
Mirek, J. (2013b). Szanse i bariery funkcjonowania lecznictwa uzdrowiskowego dzieci i młodzieży w Polsce. Zdrowie Publiczne, 43, 56-89.

Mirek, J. (2013c). Współczesne tendencje i uwarunkowania funkcjonowania i rozwoju turystyki uzdrowiskowej dzieci i młodzieży w Polsce. Handel Wewnętrzny, 45, 56-79.

Mirek, J. (2012). Klastry jako szansa rozwoju przedsiębiorstw i miejscowości uzdrowiskowych. Zeszyty Naukowe Uniwersytetu Szczecińskiego, 725.

Mursch, S. (2012). Innowacje w turystyce - studium przypadku. Zeszyty Naukowe Uniwersytetu Szczecińskiego, Współczesne Problemy Ekonomiczne, 767.

Mursch, S. (2016). Model kształtowania konkurencyjności produktu turystyki uzdrowiskowej. W: A. Szromek (red.), Wybrane aspekty zarządzania zakładem uzdrowiskowym. Kraków: Proksenia, 25-32.

Najda-Janoszka, M. (2013). Zatrzymywanie wartości z innowacji w branży turystycznej. Współczesne Zarzadzanie, 67, 23-45.

Para, A. (2014). Innowacyjny model biznesu w turystyce. Dynamika Przemian Rynku Turystycznego, $7(32), 54-76$.

OECD/Eurostat. (2006). Podręcznik Oslo: zasady gromadzenia i interpretacji danych dotyczacych innowacji. Pozyskano z: http://home.agh.edu.pl/ kkulak/lib/exe/fetch.php?media=user:konrad:vary:oslo-manual.pdf

Piotrowska, J. (2014). Stymulanty i bariery działalności innowacyjnej w kontekście rozwoju przedsiębiorstw w Polsce. Studia i Prace Wydziału Ekonomii i Zarządzania, 23, 29-45.

Ponikowska, I. (2007). Tradycja, nowoczesność i innowacyjność w lecznictwie uzdrowiskowym naszych czasów. W: XVIII Kongres Uzdrowisk Polskich. Materiały pokonferencyjne.

Rąb, K. (2015). Innowacje w zarządzaniu zasobami ludzkimi - w stronę zwrotu humanistycznego. Zeszyty Naukowe Politechniki Śląkiej, 75, 89-96.

Stańczyk-Hugiet, E. (2013). Przeżyje najlepiej dostosowany. W: R. Krupski (red.) Zarzadzanie strategiczne. Wałbrzych: Wydawnictwo Wałbrzyskiej Wyższej Szkoły Zarzadzania i Przedsiębiorczości.

Staszewska, J. (2010). Innowacyjne aspekty w powiązaniach sieciowych - możliwości wykorzystania w działalności uzdrowiskowej. W: A. Szromek (red.), Uzdrowiska i ich znaczenie w gospodarce turystycznej. Kraków: Proksenia.

Szałkowski, R. (2015). Procedury i standaryzacja w lecznictwie uzdrowiskowym. Inowrocław: Urząd Marszałkowski Województwa Kujawsko-Pomorskiego.

Szromek, A. (2016). Wybrane aspekty zarzadzania zakładem uzdrowiskowym. Kraków: Proksenia.

Szromek, A. (2014). Rola uzdrowisk i przedsiębiorstw uzdrowiskowych $w$ turystyce i w lecznictwie uzdrowiskowym. Kraków: Proksenia, 121-129.

Szromek, A. (2012). Uzdrowiska i ich funkcja turystyczno-lecznicza. Kraków: Proksenia, 121-129.

Szromek, A. (2010). Uzdrowiska i ich znaczenie w gospodarce turystycznej. Kraków: Proksenia.

Sikora, J. (1999). Uzdrowiska polskie i turystyka uzdrowiskowa w gospodarce rynkowej. W: Materiaty pokonferencyjne z I Międzynarodowej Konferencji Naukowej - Turystyka uzdrowiskowa - stan i perspektywy. Jastrzębia Góra.

Skalik, J. (2002), Zmiana warunkiem sukcesu, Wrocław.

Sudety Zdrój - dokument wewnętrzny Urzędu Marszałkowskiego Województwa Dolnoślaskiego. (2013). Wrocław.

Szałkowski, A. (2015). Procedury i standaryzacja w lecznictwie uzdrowiskowym. Inowrocław: Urząd Marszałkowski Województwa Kujawsko-Pomorskiego.

Schumpeter, J.A. (1960). Teoria rozwoju gospodarczego. Warszawa: PWN.

Tutaj, J. (2018b). Uzdrowisko w oczach swoich klientów i pracowników. W: S. Czaja, J. Tutaj, A. Becla,

N. Andreev (red.), Uzdrowiska w rozwoju zrównoważonym regionu dolnośląskiego. Wrocław: Wydawnictwo Uniwersytetu Ekonomicznego we Wrocławiu, 99-127.

Tutaj, J. (2012). Sudety Zdrój. Wrocław.

Urząd Wojewódzki Województwa Dolnośląskiego, Strategia rozwoju województwa dolnośląskiego 2020. Pozyskano z: http://www.umwd.dolnyslask.pl/fileadmin/user_upload/Rozwoj_regionalny/ SRWD/SRWD_2020-final.pdf 
Wielokulturowy kurort - nowoczesne leczenie (2016). Lądek-Zdrój.

Wołowiec, T. (1999). Problemy Gmin Uzdrowiskowych. Wspólnota Samorządowa, 6 listopada, 16.

Wołowiec, T. (2001). Proces prywatyzacji i komercjalizacji uzdrowiskowych zakładów opieki zdrowotnej. Biuletyn Stowarzyszenia Gmin Uzdrowiskowych RP, 3, 61-67.

Wołowiec T. (2001). Taksa kuracyjna źródłem dochodów własnych gmin uzdrowiskowych (rozwiązania niemiecki i austriackie). Biuletyn Informacyjny Stowarzyszenia Gmin Uzdrowiskowych $R P, 1$, 63-66.

Wołowiec, T. (2002). Kontrowersje podatkowe - podatek od nieruchomości: sanatoria i inne zakłady opieki zdrowotnej - działalność gospodarcza czy pozostała?. Biuletyn Stowarzyszenia Gmin Uzdrowiskowych RP, 1, 45-53.

Wyrzykowski, J. (2005). Turystyka a uzdrowiska: Polskie Stowarzyszenie Turystyki.

Jerzy Tutaj, dr, Wydział Informatyki i Zarządzania, Katedra Infrastruktury Zarządzania Politechniki Wrocławskiej. Absolwent Uniwersytetu Gdańskiego. Należał do założycieli Wałbrzyskiej Wyższej Szkoły Zarządzania i Przedsiębiorczości. Objął w niej kierownictwo Katedry Socjologii. W 1998 Rada Wydziału Nauk Społecznych Uniwersytetu Wrocławskiego nadała mu stopień naukowy doktora nauk humanistycznych. W latach 1996-2004 pełnił funkcję dziekana Wydziału Nauk Społecznych na wałbrzyskiej uczelni. W latach 2004-2011 był Prezesem Zarządu Przedsiębiorstwa Zamek Książ. W latach 2011-2014 był członkiem zarządu województwa dolnośląskiego. W 2014 objął stanowisko adiunkta w Katedrze Systemów Zarządzania na Wydziale Informatyki i Zarządzania Politechniki Wrocławskiej. Jest autorem kilkudziesięciu publikacji naukowych, w tym książek z zakresu strategii rozwoju, innowacji, zarządzania, a także współautorem Strategii rozwoju województwa dolnośląskiego 2020, kilkunastu strategii gmin oraz przedsiębiorstw. Jest członkiem Polskiego Towarzystwa Socjologicznego.

Jerzy Tutaj, PhD, Faculty of Computer Science and Management, Wrocław University of Science and Technology, Wrocław. He has graduated from the University of Gdańsk. He is one of the founders of Wałbrzyska Wyższa Szkoła Zarządzania i Przedsiębiorczości. He took over the leadership of the Department of Sociology. In 1998 he received a PhD in Humanities in the Faculty of Social Sciences of the University of Wrocław. In the years 1996-2004 he was the Dean of the Faculty of Social Sciences at the Wałbrzych university. Between 2004 and 2011 he was the President of the Książ Castle. In the years 2011-2014, a member of the board of the Lower Silesia Voivodeship. In 2014, he became an assistant professor in the Department of Management Systems at the Faculty of Computer Science and Management at the Wrocław University of Technology. Author of several dozen publications, including books on development strategy, innovation, management, as well as co-author of the Development Strategy for the Lower Silesian Voivodeship 2020, several strategies of municipalities and enterprises. A member of the Polish Sociological Association.

\author{
Adres/Address: \\ Politechnika Wrocławska \\ Wydział Informatyki i Zarządzania \\ Katedra Infrastruktury Zarządzania \\ Wybrzeże Wyspiańskiego 27 \\ 50-370 Wrocław, Polska \\ e-mail: jerzy.tutaj@pwr.edu.pl
}

